\title{
Konsep social cognitive career theory
}

\author{
Nilma Zola*), A. Muri Yusuf, Firman Firman \\ Department of Guidance and Counseling, Universitas Negeri Padang, Indonesia
}

\begin{tabular}{l}
\hline Article Info \\
\hline Article history: \\
Received Oct $22^{\text {nd }}, 2021$ \\
Revised Nov $26^{\text {th }}, 2021$ \\
Accepted Des $21^{\text {st }}, 2021$ \\
\hline
\end{tabular}

\section{Keyword:}

Teori karir

Pengembangan karir

Sosial cognitive

\begin{abstract}
Social Cognitive Career Theory (SCCT) is a career development model that describes how individual inputs, contextual affordances, and sociocognitive variables influence the establishment of occupational interests, career objectives, and behaviors. SCCT emphasizes the relevance of learning experiences, self-efficacy, and outcome expectations in the career development process, and is based on Bandura's social cognitive theory. SCCT is also interested in the relationships between sociocognitive characteristics, professional interests, and other career outcomes, as well as race/ethnicity, gender, and predispositions. Existing research generally supports specific SCCT approaches; nevertheless, a study of the literature found significant SCCT research limitations. The goal is for counselors to have a better grasp of the complicated mechanisms through which people establish career interests.
\end{abstract}

(C) 2022 The Authors. Published by IICET.

This is an open access article under the CC BY-NC-SA license

(https://creativecommons.org/licenses/by-nc-sa/4.0

\section{Corresponding Author:}

Nilma Zola,

Universitas Negeri Padang

Email: zola@konselor.org

\section{Pendahuluan}

Social Cognitive Career Theory (SCCT) adalah teori yang bertujuan untuk menjelaskan tiga aspek yang saling terkait dalam pengembangan karir: (1) bagaimana minat akademik dan karir dasar berkembang, (2) bagaimana pilihan pendidikan dan karir dibuat, dan (3) bagaimana kesuksesan akademik dan karier diperoleh. Teori ini menggabungkan berbagai konsep (mis., minat, kemampuan, nilai, faktor lingkungan) yang muncul dalam teori karier sebelumnya dan telah ditemukan memengaruhi pengembangan karier. Dikembangkan oleh Robert W. Lent, Steven D. Brown, dan Gail Hackett pada tahun 1994, SCCT didasarkan pada teori kognitif sosial umum Albert Bandura, sebuah teori berpengaruh dari proses kognitif dan motivasi yang telah diperluas untuk mempelajari banyak bidang fungsi psikososial, seperti kinerja akademik, perilaku kesehatan, dan pengembangan organisasi (Lent, Brown, \& Hackett, 2002). Lent et al. berusaha untuk menggabungkan aspekaspek umum dari kerangka teoritis yang sebelumnya dikembangkan dan disempurnakan oleh ahli teori karir terkenal lainnya, seperti korespondensi orang-lingkungan (Dawis, 2005), tipologi kepribadian (Holland, 1996), pembelajaran sosial (Krumboltz, Mitchell, \& Jones, 1976), life-span, life-space (Super, 2020), dan development theory (Lent, et al., 2002; Vondracek, Lerner, \& Schulenberg, 2019). Dalam pendekatan ini, mereka mampu merancang sistem yang lebih inklusif dan mampu sepenuhnya menjelaskan proses pengembangan profesional individu (Kelly, 2009; Lent, et al., 2002).

Tiga model inti SCCT diciptakan untuk lebih menjelaskan (a) bagaimana minat profesional dan akademik didirikan, (b) bagaimana pilihan karir dilaksanakan, dan (c) bagaimana hasil kinerja karir diperoleh (Lent, Brown, \& Hackett, 1994). Tiga variabel yang saling terkait, keyakinan self-efficacy, harapan hasil, dan tujuan berfungsi sebagai blok pembangun dasar SCCT. Self-efficacy mengacu pada keyakinan pribadi seseorang tentang kemampuannya untuk melakukan perilaku atau tindakan tertentu. Tidak seperti kepercayaan diri atau 
harga diri secara global, keyakinan self-efficacy relatif dinamis (dapat diubah) dan spesifik untuk domain aktivitas tertentu (Betz \& Hackett, 2006). Setiap orang memiliki self-efficacy yang berbeda mengenai perilaku yang diperlukan dalam domain pekerjaan yang berbeda. Sebagai contoh, satu orang mungkin merasa sangat percaya diri untuk dapat menyelesaikan tugas untuk berhasil masuk ke dalam, dan kinerja dalam, bidang ilmiah tetapi merasa jauh lebih tidak percaya diri tentang kemampuannya dalam bidang sosial atau giat, seperti penjualan. SCCT mengasumsikan bahwa orang cenderung menjadi tertarik, memilih untuk mengejar, dan melakukan lebih baik pada kegiatan di mana mereka memiliki keyakinan efikasi diri yang kuat, selama mereka juga memiliki keterampilan dan dukungan lingkungan yang diperlukan untuk mengejar kegiatan ini (Sheu et al., 2010).

Self-efficacy beliefs diasumsikan berasal dari empat sumber informasi utama: pencapaian kinerja pribadi, pengalaman perwakilan (mis., mengamati orang lain yang serupa), persuasi sosial, dan keadaan fisiologis dan emosional. Prestasi pribadi (keberhasilan dan kegagalan dengan tugas-tugas tertentu) diasumsikan menawarkan sumber informasi kemanjuran yang sangat menarik, tetapi sifat model sosial dan pesan yang menguatkan yang dibeberkan, dan jenis keadaan fisiologis yang dialami saat terlibat dalam bidang tertentu tugas-tugas (misalnya, tingkat kecemasan yang rendah), semua dapat mempengaruhi self-efficacy seseorang mengenai domain kinerja yang berbeda (Betz \& Hackett, 2006).

Outcome expectations mengacu pada keyakinan tentang konsekuensi atau hasil dari melakukan perilaku tertentu (mis., apa yang akan terjadi jika saya melakukan ini?). Pilihan yang dibuat orang tentang kegiatan yang akan mereka lakukan, dan upaya serta kegigihan mereka pada kegiatan ini, memerlukan pertimbangan hasil serta keyakinan self-efficacy. Misalnya, orang lebih cenderung memilih untuk terlibat dalam suatu kegiatan sejauh mereka melihat keterlibatan mereka mengarah pada hasil yang bernilai dan positif (mis., persetujuan sosial dan mandiri, imbalan nyata, kondisi kerja yang menarik). Menurut SCCT dan teori kognitif sosial yang lebih besar, keterlibatan orang dalam kegiatan, upaya dan kegigihan yang mereka lakukan, dan keberhasilan akhir mereka sebagian ditentukan oleh self-efficacy beliefs dan outcome expectations ( $\mathrm{Hsu}, \mathrm{Ju}, \mathrm{Yen}, \&$ Chang, 2007).

Personal goals dapat didefinisikan sebagai niat seseorang untuk terlibat dalam aktivitas tertentu (mis., untuk mengejar jurusan akademik tertentu) atau untuk mencapai tingkat kinerja tertentu (mis., untuk menerima nilai A dalam kursus tertentu). Dalam SCCT, kedua jenis tujuan ini, masing-masing, disebut sebagai tujuan pilihan dan tujuan kinerja. Dengan menetapkan tujuan, orang-orang membantu untuk mengatur dan membimbing perilaku mereka sendiri dan untuk mempertahankannya tanpa adanya umpan balik positif yang lebih langsung dan meskipun ada kemunduran yang tak terhindarkan. Teori kognitif sosial berpendapat bahwa tujuan penting terkait dengan efikasi diri dan harapan hasil: Orang cenderung menetapkan tujuan yang konsisten dengan pandangan mereka tentang kemampuan pribadi mereka dan hasil yang mereka harapkan untuk dicapai dari mengejar tindakan tertentu. Keberhasilan atau kegagalan dalam mencapai tujuan pribadi, pada gilirannya, menjadi informasi penting yang membantu mengubah atau mengkonfirmasi keyakinan efikasi diri dan harapan hasil (Emmons, 1996).

\section{Pembahasan}

Interest Model

Minat dalam aktivitas yang relevan dengan karir dipandang sebagai hasil dari efikasi diri dan ekspektasi hasil, seperti yang ditunjukkan pada Gambar 1. Orang-orang dihadapkan pada berbagai kegiatan yang berhubungan dengan pekerjaan di sekolah, di rumah, dan di komunitas mereka selama masa kanak-kanak dan remaja mereka, baik secara langsung maupun tidak langsung. Mereka juga dihargai secara berbeda tergantung pada berapa lama mereka tetap terlibat dan seberapa baik mereka membangun bakat mereka dalam berbagai kategori aktivitas. Jenis dan keragaman kegiatan yang dihadapi anak-anak dan remaja sebagian dipengaruhi oleh lingkungan dan budaya di mana mereka tumbuh (Lent, et al., 1994). 


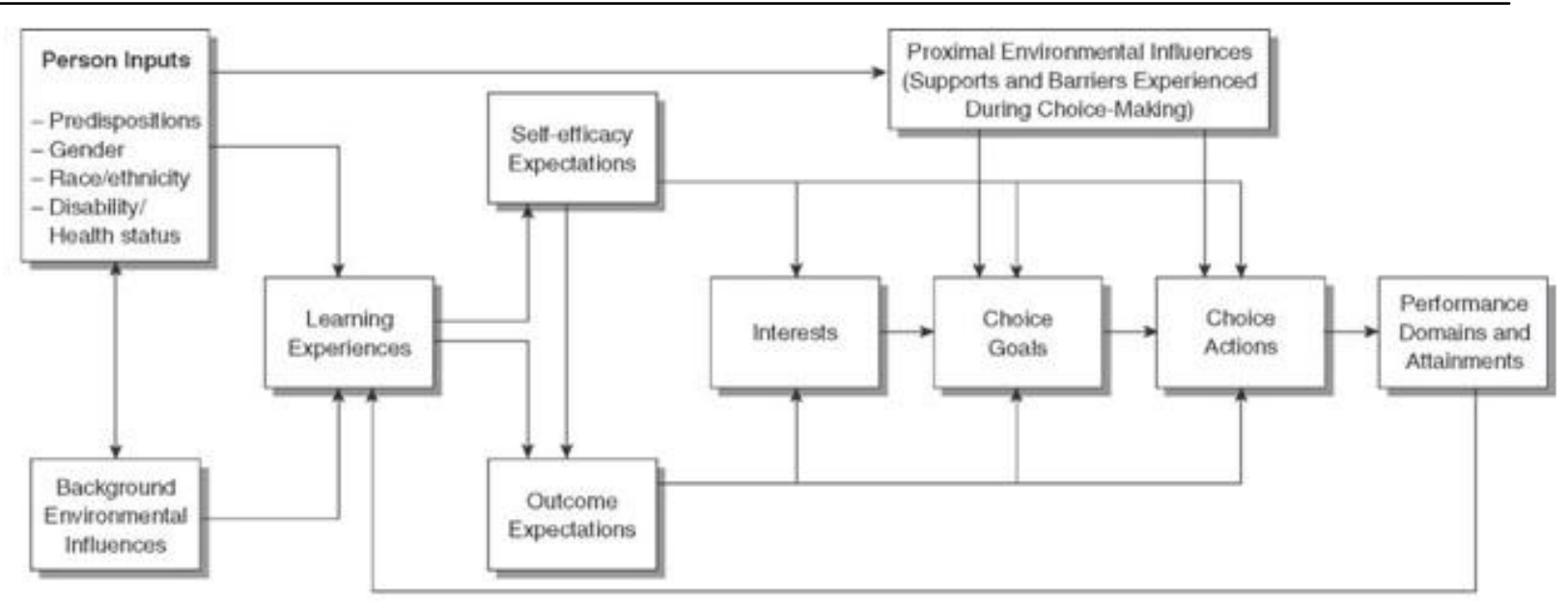

Gambar 1. Hubungan minat karir dan pembentukan pilihan (Lent, et al., 1994)

\section{SCCT's Interests Model}

Self-efficacy, outcome expectations, dan goals memainkan peran kunci dalam model pengembangan minat pendidikan dan kejuruan SCCT, membuat pilihan, dan pencapaian kinerja. Seperti yang ditunjukkan di tengah gambar di atas, minat dalam kegiatan yang relevan dengan karier dipandang sebagai hasil dari selfefficacy dan hasil harapan. Selama masa kanak-kanak dan remaja, orang-orang terpapar, secara langsung dan perwakilan, ke berbagai kegiatan yang berhubungan dengan pekerjaan di sekolah, di rumah, dan di komunitas mereka. Mereka juga dengan hormat diperkuat untuk melanjutkan keterlibatan mereka, dan untuk mengembangkan keterampilan mereka, dalam bidang kegiatan yang berbeda. Jenis dan variasi kegiatan yang anak-anak dan remaja terpapar adalah sebagian fungsi dari konteks dan budaya di mana mereka tumbuh. Tergantung pada norma-norma budaya, misalnya, anak perempuan biasanya terpapar dan diperkuat untuk terlibat dalam berbagai jenis kegiatan daripada anak laki-laki (Sheu, et al., 2010).

\section{SCCT's Choice Model}

Model proses pemilihan karier SCCT, yang dibangun berdasarkan model minat, juga tertanam dalam gambar di atas. Timbul sebagian besar melalui self-efficacy dan ekspektasi hasil, minat terkait karier memupuk tujuan pendidikan dan pilihan pekerjaan tertentu (mis., niat untuk mengejar jalur karier tertentu). Khususnya sejauh mereka jelas, spesifik, dipegang teguh, dinyatakan secara terbuka, dan didukung oleh orang-orang penting lainnya, tujuan pilihan menjadikannya lebih mungkin bahwa orang akan mengambil tindakan untuk mencapai tujuan mereka (misalnya, berusaha untuk masuk ke jurusan akademik tertentu), program pelatihan, atau pekerjaan). Pencapaian kinerja berikutnya (mis., keberhasilan, kegagalan) memberikan umpan balik yang berharga yang dapat memperkuat atau melemahkan efikasi diri dan harapan hasil dan, pada akhirnya, membantu merevisi atau mengonfirmasi pilihan (Lent, Sheu, Gloster, \& Wilkins, 2010).

\section{SCCT's Performance Model}

Model kinerja SCCT berkaitan dengan memprediksi dan menjelaskan dua aspek utama kinerja: tingkat keberhasilan yang dicapai orang dalam pengejaran pendidikan dan pekerjaan dan sejauh mana mereka bertahan dalam menghadapi hambatan. SCCT berfokus pada pengaruh kemampuan, self-efficacy, ekspektasi hasil, dan tujuan kinerja pada kesuksesan dan kegigihan. Kemampuan (sebagaimana tercermin oleh prestasi dan bakat masa lalu) diasumsikan memengaruhi kinerja melalui dua jalur utama. Pertama, kemampuan memengaruhi kinerja dan kegigihan secara langsung. Sebagai contoh, siswa dengan bakat lebih tinggi dalam mata pelajaran tertentu cenderung melakukan lebih baik dan bertahan lebih lama dalam mata pelajaran itu daripada siswa dengan bakat lebih rendah. (Kemampuan atau kecakapan dapat dianggap sebagai gabungan dari potensi bawaan dan pengetahuan yang diperoleh). Kedua, kemampuan dihipotesiskan untuk mempengaruhi kinerja dan kegigihan secara tidak langsung melalui jalur intervensi efikasi diri dan harapan hasil (S. D. Brown et al., 2008).

\section{Kekuatan dan Kelemahan Teori \\ Kekuatan}

Social Cognitive Career Theory (SCCT; Lent et al., 1994) telah menerima banyak perhatian empiris sebagai kerangka kerja untuk memahami berbagai aspek pengembangan akademik dan karir. Hackett dan Betz memperkenalkan konsep ini ke literatur psikologi kejuruan, mencatat potensinya untuk membantu menjelaskan aspek penting perilaku karir, seperti kurang representasi wanita dalam bidang karir yang didominasi pria (Sheu, et al., 2010). Pekerjaan mereka membantu memicu banyak penelitian selanjutnya yang 
menghubungkan keefektifan diri dengan pilihan dan aspek pengembangan karir lainnya dalam berbagai sampel siswa dan pekerja. Dengan banyaknya penelitian yang mengikuti rumusan teori kognitif sosial dan aplikasi awalnya untuk perilaku karir, Lent et.al mengembangkan SCCT untuk merangkum dan mengorganisir temuan terkait karir yang ada pada self-efficacy; untuk menggabungkan konsep-konsep dan prediksi-prediksi kognitif sosial lainnya yang telah diinterpretasikan dalam karir (Sheu, et al., 2010).

Sebuah studi oleh Leung, dkk., menggunakan kerangka kerja SCCT untuk menguji pengembangan karir para pemuda Italia yang menghadiri program persiapan universitas di Provinsi Padua. Penulis menemukan hubungan positif antara pencarian karir self-efficacy peserta dan dukungan keluarga, dan yang negatif hubungan antara self-efficacy pencarian karir dan ketidaktegasan karir. Untuk siswa laki-laki, hubungan antara dukungan keluarga dan keragu-raguan karier secara parsial dimediasi oleh self-efficacy pencarian karir. Temuan ini konsisten dengan model pilihan karir SCCT umum, dan menggambarkan pentingnya dukungan sosial terhadap keputusan dan keefektifan karier (Leung, 2008).

Social Cognitive Career Theory (SCCT) berkaitan dengan pekerjaan mandiri akan memprediksi tujuan mahasiswa untuk menjadi wiraswasta dalam sampel 115 mahasiswa bisnis sarjana. Hasil menunjukkan bahwa siswa dengan self-efficacy kewirausahaan yang lebih tinggi dan harapan hasil pekerjaan mandiri yang lebih tinggi memiliki minat yang lebih tinggi untuk menjadi wiraswasta. Temuan ini menyiratkan bahwa pendidik dan pembuat kebijakan dapat meningkatkan niat kewirausahaan siswa dengan (1) meningkatkan keyakinan siswa untuk berhasil dalam karir kewirausahaan dan (2) mendorong harapan siswa akan hasil positif yang kuat yang dihasilkan dari karir kewirausahaan (Segal, Borgia, \& Schoenfeld, 2002).

\section{Kelemahan}

SCCT melibatkan pemikiran kritis, konseptualisasi hasil dan komunikasi di masa depan antara klien dan konselor. Konselor harus terbuka untuk membantu individu mengidentifikasi pilihan mereka dan menyadari bahwa sikap dan keyakinan pribadi dapat menyebabkan mereka untuk membuat stereotip klien berdasarkan karakteristik seperti usia, jenis kelamin dan ras (Walsh \& Osipow, 2014). Kerangka SCCT "merangkul pandangan konstruktivis dari orang tersebut sebagai pembentuk aktif dari pengalamannya ".

Social Cognitive Career Theory (SCCT) mewakili suatu upaya baru untuk memahami proses di mana orang membentuk minat, membuat pilihan, dan mencapai berbagai tingkat keberhasilan dalam pengejaran pendidikan dan pekerjaan. Meskipun teori tersebut telah mendorong banyak penelitian dan aktivitas praktis, kebanyakan dari penelitian ini berfokus pada variabel orang-orang kognitif SCCT saja. Dalam isolasi dari lingkungan penting (misalnya, sosial, budaya, dan ekonomi) variabel yang diasumsikan mempengaruhi kedua variabel kognitif-orang dan aspek lain dari perilaku karir (Lent, Brown, \& Hackett, 2000).

Pencari kerja yang menderita penyakit mental yang parah dan terus-menerus mungkin tidak dapat sepenuhnya terlibat dalam merekonstruksi peristiwa karir masa lalu. Mereka yang menderita melalui perubahan karir yang tidak disengaja mungkin tidak siap untuk mulai mengeksplorasi dan mencari karir baru. Konselor harus mampu mengenali individu dalam keadaan sedih dan kehilangan. Konselor harus mampu memahami perasaan dan pengalaman klien dan berkomunikasi dengan mereka untuk membantu mendapatkan perspektif yang seimbang berdasarkan keadaan mereka untuk bergerak maju dengan proses perencanaan karier (Walsh \& Osipow, 2014).

\section{Aplikasi Teori dalam Bimbingan dan Konseling}

Sebagai konselor karir yang berorientasi pada ilmu pengetahuan, SCCT dapat digunakan sebagai kerangka integratif untuk menggambar bersama sudut pandang dan hipotesis orisinal lain yang telah menghasilkan dukungan dalam literatur karir. Sebagai contoh, penelitian menunjukkan pentingnya membantu klien untuk mengidentifikasi kemungkinan pekerjaan yang sesuai dengan kepentingan mereka dan itu sesuai dengan nilai dan kemampuan mereka .Penelitian terbaru juga menunjukkan kegunaan untuk mempertimbangkan "persyaratan inti" klien untuk pekerjaan. Dengan demikian, selain dimensi penilaian yang lebih tradisional, juga dapat mengidentifikasi apa yang paling mereka inginkan dari sebuah karir dan untuk menganalisis kemungkinan vocasional untuk sejauh mana mereka dapat memenuhi persyaratan inti ini. Dari perspektif SCCT, pendekatan semacam itu dapat memastikan bahwa klien-klien ini mendasarkan keputusan akhir mereka pada suatu yang relatif lengkap dan harapan hasil yang akurat (D. Brown, 2002).

\section{Simpulan}

Social Cognitive Career Theory (SCCT) adalah teori yang bertujuan untuk menjelaskan tiga aspek yang saling terkait dalam pengembangan karir. Teori ini menggabungkan berbagai konsep (misalnya minat, kemampuan, nilai, faktor lingkungan). Sebagai model inti SCCT diciptakan untuk lebih menjelaskan (a) bagaimana minat profesional yang saling terkait, keyakinan self-efficacy, harapan hasil, dan tujuan berfungsi sebagai blok 
pembangun dasar. SCCT menerima banyak perhatian empiris sebagai kerangka kerja untuk memahami berbagai aspek pengembangan akademik dan karir. Pekerjaan mereka mengikuti rumusan teori kognitif sosial lainnya dalam aplikasi awalnya. SCCT mewakili suatu upaya baru untuk memahami proses di orang membentuk minat, membuat pilihan, dan mencapai berbagai tingkat keberhasilan dalam pengejaran pendidikan dan pekerjaan. Sama halnya dengan banyak teori karir yang lain, SCCT juga memiliki kekuatan dan kelemahan, sehingga sebagai konselor karir perlu untuk memiliki pemahaman yang mendalam berkaitan dengan berbagai teori karir khususnya SCCT.

\section{Referensi}

Betz, N. E., \& Hackett, G. (2006). Career self-efficacy theory: Back to the future. Journal of career assessment, 14(1), 3-11.

Brown, D. (2002). Career choice and development: John Wiley \& Sons.

Brown, S. D., Tramayne, S., Hoxha, D., Telander, K., Fan, X., \& Lent, R. W. (2008). Social cognitive predictors of college students' academic performance and persistence: A meta-analytic path analysis. Journal of Vocational Behavior, 72(3), 298-308.

Dawis, R. V. (2005). The Minnesota Theory of Work Adjustment.

Emmons, R. A. (1996). Striving and feeling: Personal goals and subjective well-being.

Holland, J. L. (1996). Exploring careers with a typology: What we have learned and some new directions. American psychologist, 51(4), 397.

Hsu, M.-H., Ju, T. L., Yen, C.-H., \& Chang, C.-M. (2007). Knowledge sharing behavior in virtual communities: The relationship between trust, self-efficacy, and outcome expectations. International journal of human-computer studies, 65(2), 153-169.

Kelly, M. E. (2009). Social cognitive career theory as applied to the school-to-work transition: Seton Hall University.

Krumboltz, J. D., Mitchell, A. M., \& Jones, G. B. (1976). A social learning theory of career selection. The counseling psychologist, 6(1), 71-81.

Lent, R. W., Brown, S. D., \& Hackett, G. (1994). Toward a unifying social cognitive theory of career and academic interest, choice, and performance. Journal of vocational behavior, 45(1), 79-122.

Lent, R. W., Brown, S. D., \& Hackett, G. (2000). Contextual supports and barriers to career choice: A social cognitive analysis. Journal of counseling psychology, 47(1), 36.

Lent, R. W., Brown, S. D., \& Hackett, G. (2002). Social cognitive career theory. Career choice and development, 4, 255-311.

Lent, R. W., Sheu, H.-B., Gloster, C. S., \& Wilkins, G. (2010). Longitudinal test of the social cognitive model of choice in engineering students at historically Black universities. Journal of Vocational Behavior, 76(3), 387-394.

Leung, S. A. (2008). The big five career theories International handbook of career guidance (pp. 115-132): Springer.

Segal, G., Borgia, D., \& Schoenfeld, J. (2002). Using social cognitive career theory to predict self-employment goals. New England Journal of Entrepreneurship, 5(2), 47-56.

Sheu, H.-B., Lent, R. W., Brown, S. D., Miller, M. J., Hennessy, K. D., \& Duffy, R. D. (2010). Testing the choice model of social cognitive career theory across Holland themes: A meta-analytic path analysis. Journal of Vocational Behavior, 76(2), 252-264.

Super, D. (2020). Life-Span, Life-Space Career Theory and Counseling. Career Development and Counseling: Putting Theory and Research to Work, 95.

Vondracek, F. W., Lerner, R. M., \& Schulenberg, J. E. (2019). Career development: A life-span developmental approach: Routledge.

Walsh, W. B., \& Osipow, S. H. (2014). Career decision making: Routledge. 